\title{
PELACURAN DAN PENANGGULANGANNYA DALAM PERSPEKTIF POLITIK HUKUM PIDANA
}

\author{
Jatmiko Winarno, SH,MH
}

\begin{abstract}
Abstrak
Pelacuran sebagai sebuah nama yang diberikan untuk suatu perbuatan yang di dalamnya terlibat beberapa orang dalam suatu peristiwa. Perbuatan di mana seorang perempuan menyerahkan dirinya untuk berhubungan kelamin dengan lawan jenisnya yang mengharapkan bayaran berupa uang atau bentuk lainnya. Pelacuran merupakan masalah sosial dalam kehidupan bermasyarakat, karena merugikan keselamatan, ketentraman, kemakmuran jasmani dan rohani. Hal ini pun menjadi sesuatu yang nyata agar segera ditanggulangi bila dihubungkan dengan cara pandang agama dan adat tradisi suku bangsa di Indonesia.

Masalah pelacuran harus dilihat sebagai gejala sosial yang nampak jelas bertentangan dengan ketertiban dan kehidupan masyarakat secara umum. Akibat yang ditimbulkan akan menghambat proses perkembangan pada suatu masyarakat. Namun demikian terlihat tidak ada suatu kaidah hukum dari negara manapun yang mampu meniadakan pelacuran dalam arti menindak gejala tersebut seperti halnya kejahatan semacam pembunuhan, pencurian, penipuan dan lain sebagainya yang dapat menjatuhkan sanksi, dengan tegas baik hukuman mati, hukuman penjara, maupun hukuman denda.
\end{abstract}

\section{Kata Kunci : Pelacuran}

\section{A. Pendahuluan}

\section{Latar Belakang Masalah} Hampir semua negara di dunia ini, baik negara maju, berkembang, maupun negara miskin sekalipun menghadapi masalah tersendiri dalam menangani problem sosial, terutama berupa pelacuran. Banyak dibaca dalam surat kabar, majalah, kajian buku maupun ulasan-ulasan mengenai pelacuran dan penanggulangannya, namun ada kecenderungan masalah pelacuran ini tidak memperlihatkan tendensi menurun. Malahan penanggulangan gejala sosial tertua dan abadi ini semakin kurang menggigit.

Pelacuran sebagai sebuah nama yang diberikan untuk suatu perbuatan yang di dalamnya terlibat beberapa orang dalam suatu peristiwa. Perbuatan di mana seorang perempuan menyerahkan dirinya untuk berhubungan kelamin dengan lawan jenisnya yang mengharapkan bayaran berupa uang atau bentuk lainnya. Pelacuran merupakan masalah sosial dalam kehidupan bermasyarakat, karena merugikan keselamatan, ketentraman, kemakmuran jasmani dan rohani. Hal ini pun menjadi sesuatu yang nyata agar segera ditanggulangi bila dihubungkan dengan cara pandang agama dan adat tradisi suku bangsa di Indonesia.

Masalah pelacuran harus dilihat sebagai gejala sosial yang 
nampak jelas bertentangan dengan ketertiban dan kehidupan masyarakat secara umum. Akibat yang ditimbulkan akan menghambat proses perkembangan pada suatu masyarakat. Namun demikian terlihat tidak ada suatu kaidah hukum dari negara manapun yang mampu meniadakan pelacuran dalam arti menindak gejala tersebut seperti halnya kejahatan semacam pembunuhan, pencurian, penipuan dan lain sebagainya yang dapat menjatuhkan sanksi, dengan tegas baik hukuman mati, hukuman penjara, maupun hukuman denda. ${ }^{54}$

Bagi pelacur andaikata yang tertangkap dimasukkan penjara maka bagaimanapun penjara akan kewalahan. Belum lagi jika semua pihak yang berperan dalam pentas pelacuran ikut pula dipenjara, maka persoalan lainnya menjadi tidak terurus. Lebih tidak mungkin lagi bila demi keadilan para pelanggan yang tertangkap juga ditindak meski sebenarnya mereka pun terkait dalam drama pelacuran ini.

Dihadapkan dengan gejala sosial ini hukum tidak mampu berperan layaknya menangani gejala sosial lainnya secara penuh karena ia menghadapi kebutuhan yang amat vital dalam kehidupan manusia sesuai dengan sifat alaminya, sehingga dalam hal demikian hukum hanya bisa berusaha menganalisa agar sekalipun prostitusi ada namun tidak meluas secara pesat dan diusahakan dicegah serta dikurangi

${ }^{54}$ Soedjono.D, Pelacuran Ditinjau Dari Segi Hukum Dan Kenyataan Dalam Masyarakal, Karya Nusantara, Bandung, 1977, ha1.58. akibat-akibatnya. Hal ini terbukti dalam sejarah bahwa dengan tindakan kekerasan dan siksaan terhadap para pelacur, drama pelacuran tetap ada dari masa ke masa sepanjang jaman. ${ }^{55}$

Kebijakan-kebijakan hukum yang selama ini berusaha mengontrol masalah mi dinilai oleh banyak kalangan belum menyentuh pada usaha meminimalisir angka pelacuran yang semakin meresahkan masyarakat luas. Pendekatan penal berupa pemidanaan yang selama ini diterapkan berupa razia-razia rutin dan mengenakan mereka dengan pidana tindak pidana ringan (tipiring) berupa kurungan maupun pembayaran denda belum mampu mengatasi fenomena sosial ini. Pendekatan non penal berupa kebijakan-kebijakan yang diterapkan oleh banyak Pemda dalam aturan-aturan Perda pun belum mampu menyentuh masalah ini agar sedikit banyaknya bisa diminimalisir, seminal penyaluran para pelaku pelacuran ini ke dinas-dinas sosial agar mereka memiliki ketrampilan yang dapat mereka pergunakan dalam kehidupan bermasyarakat nantinya.

Berdasar pemikiran tersebut di atas dan realitas yang terjadi maka dalam masalah ini kajian politik hukum pidana (penal policy) yang di dalamnya tidak hanya berupa sebagai usaha yang berkaitan dengan pembentukan aturan-aturan yang berusaha membatasi, meminimalisir usaha pencegahan beserta penerapan hukum tentang

${ }^{55}$ Ibid, hal. 59 
pelacuran dan segala sesuatu yang ada di dalamnya sehingga tercipta sebuah keselarasan dalam ketertiban, keamanan, dan kesejahteraan kehidupan bermasyarakat sesuai apa yang di cita-citakan hukum itu sendiri. Tetapi juga berisi tentang kebijakankebijakan sosiologis yang bersandar pada nilai-nilai sosial yang sangat erat hidup dalam masyarakat dan melandasi serta memberi isi terhadap muatan normatif substantif hukum pidana yang dicita-citakan.

Tujuan akhir dari kebijakan kriminal pun dalam melihat realitas yang ada di atas juga menjadi sebuah komponen yang penting di mana berisi "perlindungan masyarakat" untuk mencapai tujuan utama yang sering disebut dengan berbagai istilah misalnya "kebahagiaan warga masyarakat/penduduk "(happiness of the citizens), "kehidupan kultural yang sehat dan menyenangkan " $(a$ wholesome and cultural living), "kesejahteraan masyarakat" (sosial welfare) atau untuk mencapai keseimbangan" (equality).

Selama ini banyak terjadi masalah ketika kebijakan-kebijakan yang dilakukan oleh pemerintah atau Pemda semisal pembuatan lokalisasi justru terkesan melegalkan pelacuran. Selama ini ada kesan bahwa pekerja seks komersil atau WTS yang harus ditindak, padahal mata rantai dari drama pelacuran ini amat kompleks. WTS, germo, mucikari pelanggan adalah pelaku yang tidak hanya salah satu atau sebagian dari mereka diputus maupun ditindak begitu saja. Tetapi penanganan mereka secara komprehensif dengan memidana pun bukan pekerjaan yang mudah. Kasus-kasus mereka cukup banyak dan pembinaan dengan pemidanaan penjara akan menimbulkan keruwetan baru. Aturan hukum dalam KUHP yang masih terlihat samar pun merupakan salah satu faktor mengapa pelacuran sangat sulit ditangani. Hal ini bisa dibuktikan bila kita memeriksa KUHP dimana di dalamnya sangat minim dan sederhana sekali pasalpasal yang berhubungan dengan pelacuran.

\section{Perumusan Masalah}

Berdasarkan uraian tersebut di atas maka timbul permasalahan yang dapat dirumuskan sebagai berikut :

a. Bagaimana ketentuan hukum positif tentang pelacuran yang ada sekarang ini ditinjau dan segi kebijakan hukum pidana ?

b. Bagaimana kebijakan hukum pidana yang ideal untuk menanggulangi masalah pelacuran?

\section{Tujuan Penelitian}

Ada pun yang menjadi tujuan dilakukannya penelitiaan ini adalah :

a. Untuk mengetahui ketentuan hukum positif tentang pelacuran yang ada sekarang ini ditinjau dari segi kebijakan hukum pidana.

b. Untuk mengetahui kebijakan hukum pidana yang ideal sehingga mampu menanggulangi masalah pelacuran. 


\section{B. Kajian Pustaka}

\section{Pengertian Pelacuran}

Maksud kata pelacuran dalam penulisan ini memang identik dengan istilah asing yaitu prostitusi yang berasal dari pengertian bahasa Latin "prostituo" arti menyerahkan diri secara terangterangan dalam perzinahan. Kalau perzinahan menurut hukum sendiri merupakan hubungan badan yang dilakukan oleh seseorang baik yang sudah memiliki suami ataupun istri dengan orang lain yang diketahui bukan suami atau istrinya. Dengan kata lain sebenarnya perzinahan itu dilakukan oleh lelaki maupun wanita sehingga bisa dibenarkan pendapat selama ini bahwa pelacuran biasa dilakukan oleh seorang wanita ataupun seorang lelaki meskipun hal ini relatif jarang terekspos secara nyata.

Melihat dari sejarah yang ada bahwa pada zaman dahulu pelacuran diartikan sebagai perbuatan menyerahkan diri pada banyak laki-laki dengan pembayaran sejumlah uang tertentu. Hubungan yang mereka lakukan diartikan sama dengan apa yang dilakukan oleh suami istri dalam ikatan perkawinan yang sah.

Secara tinjauan umum pendapat yang berkembang selama ini dan selalu dijumpai dalam praktek kehidupan sehari-hari yang biasa berperan dalam pelacuran ini cenderung perempuan. Mereka dalam sehari mampu berhubungan badan dengan para tamu yang datang sampai berulang kali disertai dengan pembayaran sejumlah uang sesuai kesepakatan awal yang mereka setujui. Melakukan persebadanan sampai berulang kali ini memang dimungkinkan bagi seorang perempuan, karena secara kodrati mereka mampu berulang kali melakukan hal tersebut meski dengan perasaan tertekan, malu, marah, atau sebagainya. Sangat berbeda dengan laki-laki, bila mereka meyerahkan diri seperti apa yang terungkap di atas hal itu sangat tidak dimungkinkan karena kodrat laki-laki tidak memungkinkan melakukan persebadanan secara berturut-turut.

Selama ini penelitianpenelitian yang ada selalu menunjukan bahwa seseorang lakilaki mengunjungi tempat pelacuran adalah untuk melakukan persebadanan dengan seorang wanita yang berprofesi sebagai pelacur. Atau pun juga bisa dimungkinkan memanggil pelacur panggilan atau biasa yang disebut call girl untuk menemani mereka bercumbu rayu yang tempatnya bisa di mana saja, baik itu di hotel, rumah pribadi, atau mungkin villa. Tetapi banyak juga pelanggan atau para tamu pria tersebut mengunjungi rumah-rumah bordil tidak hanya untuk melakukan hubungan seksuil, tapi hanya mencari kepuasankepuasan tertentu dengan melakukan gerakan-gerakan tertentu yang mampu bisa memuaskan hasrat mereka.

Dengan pemaparan yang ada di atas bisa disimpulkan bahwa pelacuran adalah "penyerahan diri

${ }^{56}$ Soedjono D., Op.Cit, hal. 14 
yang dilakukan oleh wanita untuk berhubungan badan lawan jenisnya, yaitu para tamu dengan kesepakatan pembayaran sejumlah tertentu". ${ }^{57}$

Hal-hal tersebut mengandung arti sebagai berikut :

a. Penyerahan diri seorang wanita.

b. Berhubungan badan dengan lawan jenis

c. Dengan membayar sejumlah tertentu sesuai kesepakatan.

Penyerahan diri yang

dilakukan wanita terhadap lawan jenisnya dengan memperoleh pembayaran uang tertentu cenderung merupakan sebuah mata pencaharian. Hal ini sangat bertentangan dengan norma-norma yang ada pada masyarakat timur kita. Para pelacur yang merasa memiliki mata pencaharian seperti ini dianggap merusak tatanan kehidupan masyarakat. Mereka dianggap nista dan menjadi sampah masyarakat yang harus dikucilkan, padahal drama dari pelacuran yang terjadi saat ini amat komplek dan sangat susah untuk mencari akar masalahnya, karena mereka sebenarnya bukan akar dari masalah ini.

Di Indonesia sendiri banyak istilah untuk menyebut mereka yang berprofesi sebagai pelacur ini. Sebutan itu sangat beraneka ragam yang antara lain semisal: telembuk, lonte, ublak, sundal, dan lain sebagainya. Yang arah sebenarnya untuk mengucilkan mereka dari pergaulan masyarakat yang masih kuat memegang tatanan kehidupan yang berlandaskan aturan agama dan

${ }^{57}$ Ibid, hal. 16 moral. Dalam menjalankan praktek pelacuran ini para pelacur berbedabeda dalam menjalankan kegiatannya. Mereka ada yang melakukan aktifitasnya secara sendri-sendiri, dan ada yang dikoordinir oleh seorang germo yang biasa mereka sebut sebagai mami atau papi.

Ada banyak ahli berpendapat untuk lebih memperdalam arti pelacuran itu sendiri. Pendapat dan rumusan para ahli itu antara lain :

a. Iwan Bloch: "Die Prostitution ist eine bestimmte form des ausserehelichen geslechtsverkohre, die dadurch ausgesiech net ist, duss das sich prostiurende individimuum mehr oder winiger wahllos sich unbestimmt vielen personen fortgestzt, offentlich and noterisch, selten ahne entgelt meist in der form der gewerbsmassigen kanflichtket zum beischlafe oder zu anderen geschlechtliche hundlungen friedigung verschaft und proverziert und in folge dieses unzuchtgewerbes linen bestimuten konstanten typus bekommt". Diartikan bahwa pelacuran adalah suatu bentuk tertentu dari perhubungan kelamin di luar perkawinan, dengan pola tertentu yaitu kepada siapapun pun secara terbuka, dan hampir selalu dengan pembayaran, baik untuk persebadanan, ataupun kegiatan seks lainnya yang memberi kepuasan yang diinginkan oleh yang bersangkutan. Perbuatan ini dilakukan sebagai mata pencaharian dan sebagai akibat dari pekerjaan itu si pelacur menunjukkan sebagai tipe tertentu. 
b. George Ryley Scoot: "A prostitute is an individual, male or female, who for some kind or reward, monetary or otherwise, or for some form or personal satisfication, and as part wholetime profession, angages in normal or abnormalsexual intercourse with various persons, who may be of the some sex as or the opposite sex to the prostitute". Diartikan pelacur adalah seorang laki-laki atau perempuan, yang karena semacam upah, baik berupa uang atau yang lainnya, atau karena semacam bentuk kesenangan pribadi dan sebagai bagian atau seluruh pekerjaanya, mengadakan perhubungan kelamin yang normal atau tidak normal dengan berbagai orang, yang sejenis dengan atau yang berlawanan jenis dengan pelacur itu.

c. Commenge: "La prostitution (est) I'acte per I'acte lequel one femme, faisant commerce deson corps, se livre au premier venu, moyenmant ranumeration at n'a d'autre mayens de'exsistence que cuexque lui procurent les relations pasaage res qu'elle entretioent avecun plus on mains grand d'individus". Artinya prostitusi adalah suatu perbuatan di mana seorang wanita memperdagangkan atau menjual tubuhnya, yang dilakukan untuk memperoleh pembayaran dari laki-laki yang datang membayarnya, dan wanita tersebut tidak ada mata pencaharian lain lagi dalam hidupnya, kecuali yang diperolehnya dari perhubungan sebentar-sebentar dengan banyak orang.

d. Walter C. Rechless: "Prostitution is the practice of selling sexual intercourse or other substitute forms of sexual gratification“. Menurut rumusan ini maka tidak terbatas pada persebadanan dan hubungan kelamin semata, melainkan juga berbagai bentuk pemuasan sex lainnya. ${ }^{58}$

Itulah beberapa batasan para ahli di atas yang menaruh perhatian sangat besar dalam menyikapi penyakit masyarakat tersebut. Pengertian di atas akan dijadikan batasan penjabaran selanjutnya agar dapat lebih memahami arti pelacuran dari beberapa pengertian yang dituangkan oleh beberapa kalangan. Hal-hal yang dapat digarisbawahi sebenarnya adalah berkenaan pada hal penamaan menjual diri yang terkandung di dalam pentas pelacuran, rupanya dipakai dalam masyarakat untuk memberi predikat kepada orangorang yang menjual diri, untuk memperoleh penghasilan.

Penyakit masyarakat yang menjadi fenomena sosial dan terlihat sangat umum ini memang mendapat reaksi keras dari masyarakat Indonesia sendiri sebagai sebuah negara yang memegang teguh norma, adat, dan agama yang hidup dalam masyarakat. Dasar pelarangan ini terlihat cukup beralasan karena dengan pekerjaan yang mereka lakukan, dalam hal ini subyek yang ikut terlibat dalam pelacuran, tatanan kehidupan masyarakat yang memiliki kaidah-kaidah dan norma pun ikut terlanggar.

Berhubungan badan dalam pola pikir masyarakat adalah sesuatu yang sah dilakukan oleh sepasang suami istri bila sudah terikat dalam

${ }^{58}$ Ibid, hal. 17-18 
perkawinan yang sah, bukan dilakukan sebagai sebuah pekerjaan karena titik tolaknya dikhawatirkan membuat semakin merosotnya nilai moralitas masyarakat yang selama ini berusaha dijaga dan dipertahankan. Bagi masyarakat timur pelacuran merupakan sebuah hal yang sangat nista dan hanya dilakukan oleh mereka yang tidak memilik kepekaan moral. Terlepas dari itu dari berbagai faktor yang melatarbelakangi terjadinya pelacuran, tetapi pandangan ini sedikit banyaknya menjadi sebuah pembenaran yang terjadi dalam masyarakat dan tidak dapat terbantahkan.

Dasar moralitas yang selama ini melarang pelacuran memang tidak dapat terlepas dari kehidupan masyarakat dalam hidup bermasyarakat yang memiliki beragam kepentingan. Kepentingankepentingan itu merupakan tuntutan perseorangan atau kelompok yang diharapkan dapat dipenuhi. ${ }^{59}$ Kepentingan-kepentingan manusia tersebut dibatasi oleh berbagai kaidah sosial yang hidup dan mengatur kehidupan pribadi maupun kehidupan antar pribadi. Kaedah kesusilaan misalnya yang berhubungan dengan manusia sebagai individu karena menyangkut kehidupan pribadi manusia, dalam hal ini ditujukan kepada umat manusia agar terbentuk kebaikan ahlak pribadi guna penyempurnaan

\footnotetext{
59 Soedikno Mertokusumo, Mengenal Hukum Suatu Pengantar, Liberty, Yogyakarta, 1998, hal 1
}

manusia dan melarang manusia melakukan perbuatan jahat" ${ }^{60}$

Kaidah agama juga, yang dalam arti sempit adalah hubungan manusia dengan Tuhannya dimana hubungan itu mengandung kewajiban-kewajiban terhadap Tuhan sebagai cinta terhadap Tuhan. Kewajiban-kewajiban itu benarbenar bersifat keagamaan sejati, yang karena isinya diperbedakan baik dari kewajiban moral maupun dari kewajiban hukum. $^{61}$ Meskipun kaidah agama ini tidak mendapat sanksi secara langsung tetapi kaidah ini ditujukan kepada sikap batin manusia agar mencapai penyempurnaan manusia karena itu yang diharapkan oleh Tuhan.

Begitupula dengan kaidah sopan santun yang hidup dalam masyarakat merupakan salah satu dasar moralitas pelacuran menjadi sesuatu hal yang sangat nista dan mendapat reaksi sangat keras. Kaidah ini meski bila dilanggar hanya menimbulkan cemoohan, celaan, atau umpatan tetapi kaidah ini juga cukup membatasi kehidupan masyarakat agar menjadi lebih baik.

Kaidah-kaidah tersebut di atas dalam pemberian sangsi memang dirasa tidak terlihat tegas secara langsung dirasakan oleh para subyek dalam pelacuran, tetapi ini tidak berarti bahwa ketiga kaidah tersebut tidak bermanfaat. Kaidahkaidah tersebut memiliki peranan dan kegunaan dalam masyarakat

${ }^{60}$ Ibid, hal. 7

${ }^{61}$ Van Apeldoorn, Pengantar Ilmu Hukum, Cetakan ke lima, Liberty, Yogyakarta, 2000, hal. 29 
secara keseluruhan selama ini karena digunakan sebagai dasar moralitas pada suatu perbuatan yang dianggap tidak baik oleh masyarakat.

Pelacuran dalam sudut
pandang agama menyangkut
masalah nilai-nilai baik itu
menyangkut nilai yang baik ataupun nilai yang buruk. Penilaian terhadap nilai tersebut tersirat dalam sumber hukum Islam yaitu A1 Qur'an dan Al Hadist. Dalam Al Qur'an tidak ada ayat yang menyebutkan masalah pelacuran, tetapi hanya mengenai perzinahan. Kata perzinahan lebih luas maksudnya dibandingkan pelacuran, karena pelacuran merupakan salah satu bentuk perzinahan. Mengenai perzinahan itu sendiri dapat diartikan bahwa :

"Zina, yakni perhubungan kelamin antara laki-laki dengan perempuan diluar perkawinan termasuk ke dalamnya baik perempuan itu kawin apa tidak, pendapat yang meliputi kejadiankejadian yang terutama dan lebih banyak masyarakat yaitu perhubungan kelamin laki-laki dan perempuan di luar perkawinan karena Islam sendiri mempunyai pula istilah perhubungan kelamin antar dua orang dengan kelamin yang sama, baik sama-sama perempuan maupun sama lakilaki". ${ }^{62}$

62 Ali Akbar, Pelacuran dan Penyakit Kelamin, Dian Kemaka, Departemen Sosial RI, Jakarta, tt, hal. 114
Mengenai sanksi yang diancamkan oleh Allah terdapat dalam surat An Nuur ayat 2 dan 3, yaitu :

"Pezina laki-laki dan pezina perempuan deralah mereka masingmasing 100 kali, dan dalam menjalankan ketentuan Allah janganlah ada rasa kasihan kalau kamu betul-betul beriman kepada Allah dan hari yang akhir. Hendaklah ada orang yang mengawasi pelaksanaan hukuman yang terdiri atas orang-orang yang beriman. Seorang laki-laki pezina tidak boleh menikah kecuali dengan perempuan yang pezina atau perempuan musyrik, pezina perempuan pun tidak dapat dinikahi kecuali oleh pezina laki-laki atau seorang musyrik, yang demikian itu haram hukumnya bagi orang beriman". ${ }^{63}$

Dari beberapa sumber di atas dapat disimpulkan bahwa pelacuran dalam sudut pandang agama adalah perbuatan haram yang diancamkan sanksi berat di dunia maupun di akhirat. Indonesia sendiri yang sebagian besar penduduknya beragama Islam menyadari hal tersebut diyakini mereka sebagai perbuatan yang sangat berdosa berdasar ajaran agama, dan merupakan masalah yang harus terus dicari jalan keluarnya.

Kajian sosial dalam masalah pelacuran ini harus pula menjadi perhatian utama yang memilik porsi tertentu mengingat masalah

63 Zaini Dahlan dan Sahil Azharudin, Al Qur'an Karim dan Terjemahan Artinya, UII Press, Yogyakarta, ha1.611-612 
pelacuran adalah masalah sosial. Dalam kehidupan sosial manapun pelacuran sangat dikutuk karena mereka menganggap sebagai sampah masyarakat yang dapat membuat turunnya moralitas dalam kelompok masyarakat tertentu. Pelacuran merupakan kejahatan dimana diklasifikasikan pada perbuatan manusia yang bertentangan dengan hukum.

Kejahatan itu sendiri merupakan salah satu bentuk gejala sosial yang berkenaan dengan individu atau masyarakat. Rumusan kejahatan ini menurut Paul Mudigdo Moeliono merupakan perbuatan manusia yang merupakan pelanggaran norma. yang dirasakan merugikan, menjengkelkan, sehingga tidak boleh dibiarkan. ${ }^{64}$

Kaitannya dengan pelacuran yang tidak mungkin dapat dihapuskan tapi hanya bisa diupayakan diminimalisir, sedapat mungkin sebagai masalah sosial, pelacuran ini ditanggulangi dengan berbagai macam pola kebijakan sambil mencari cara yang lebih efektif untuk mengatasinya. ${ }^{65}$ Namun manusia dan masyarakat sosial pada umumnya menganggap masalah pelacuran adalah sebuah hal biasa karena budaya yang dikondisikan masyarakat itu sendiri. Mereka hanya memberi sanksi sosial berupa cemoohan, umpatan tanpa ada upaya meminimalisir masalah

64 Soedjono D. Dikutip oleh Mudzakkir dalam Peranan Psikologi dalam Penerapan Hukum Pidana, FH-UII, Yogyakarta, 1985, hal. 19.

65 Ibiid ini agar dapat tertanggulangi, padahal justru sikap seperti itu yang diperlukan.

\section{Pengertian Politik Hukum Pidana}

Politik hukum pidana yang selama ini diketahui, dapat pula disebut dengan kebijakan hukum pidana yang di dalamnya berisi berbagai macam cara penentuan sebuah kebijakan hukum dalam hukum pidana. Seperti apa yang diungkapkan Sudario, bahwa politik hukum pidana adalah usaha untuk mewujudkan peraturan-peraturan yang dikeluarkan oleh negara melalui badan-badan yang berwenang dan diperkirakan berguna untuk mengekspresikan apa yang terkandung di dalam masyarakat dan untuk mencapai apa yang dicita-citakan. ${ }^{66}$

Dari kebijakan yang dikeluarkan oleh badan yang berwenang tersebut akan tercipta sebuah kerangka hukum yang memayungi sebuah permasalahan yang muncul dalam masyarakat modern yang memiliki kompleksitas kehidupan.

Sudario juga mengungkapkan bahwa politik hukum pidana merupakan usahausaha untuk mewujudkan peraturanperaturan yang baik sesuai dengan keadaan dan situasi saat itu. ${ }^{67}$

Politik Hukum Pidana menurut pengertian Abdul Hakim Garuda Nusantara seperti yang

${ }^{66}$ Udarto, Op.Cit, hal. 20

${ }^{67}$ Ibid, hal. 27 
dikutip oleh Moh. Mahfud dan pernah penulis ungkapkan di bagian depan, menyatakan bahwa kebijaksanaan hukum (legal policy) yang hendak atau telah dilaksanakan secara nasional oleh pemerintah Indonesia, yang dalam implementasinya meliputi :

a. Pembangunan hukum yang berintikan pembuatan hukum dan pembaharuan hukum terhadap bahan-bahan hukum yang dianggap asing atau tidak sesuai dengan kebutuhan dengan penciptaan hukum yang diperlukan.

b. Pelaksanaan ketentuan hukum yang telah ada, termasuk penegasan fungsi lembaga dan pembinaan anggota penegak hukum. ${ }^{68}$

Berdasarkan hal yang diungkapkan di atas terlihat jelas bahwa dalam penentuan kebijakan hukum terhadap sebuah masalah yang ada di dalam masyarakat harus mengedepankan segala sesuatu yang ada dalam masyarakat. Peran serta masyarakat dalam hal pengambilan kebijakan perlu diakomodir sehingga nantinya usaha yang diharapkan dalam tahap legislatif, tahap eksekutif dan tahap aplikatif dapat berjalan dengan seimbang sesuai dengan yang diharapkan.

dilakukan dalam hal penanggulangan kejahatan memang dapat berupa penal approach dan non penal approach, tetapi usaha lewat pembuatan undang-undang hukum pidana yang sesuai pada dasarnya merupakan bagian dari kesatuan yang utuh sebagai suatu perlindungan masyarakat (social defence). Untuk itu dapat pula diartikan bahwa politik hukum pidana juga bagian dari politik sosial. Dalam skema di bawah ini hubungan itu dapat digambarkan ${ }^{69}$

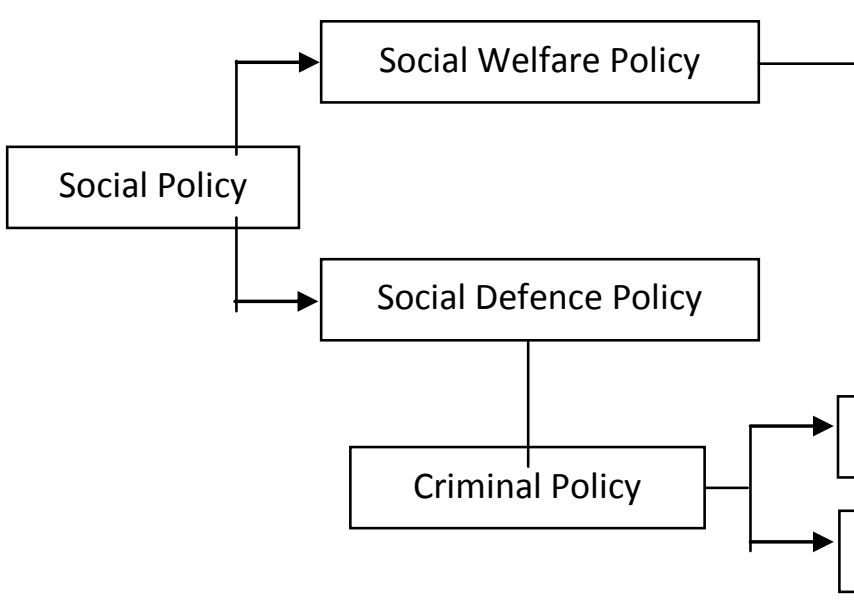

Pada dasarnya dalam pola hidup masyarakat yang heterogen saat ini, sering timbul konflik dalam masyarakat sebagai bagian dari proses interaksi sosial. Masyarakat dalam berprilaku terbingkai dalam aturan-aturan hukum, yang salah satunya adalah hukum pidana. Hukum pidana dalam masyarakat digunakan alat pencegahan. Sebelum penentuan kebijakan hukum itu tertuang untuk ditaati bersama, pidana sebagai alat pencegahan berupaya diterapkan secara sungguh-sungguh untuk mencegah timbulnya kejahatan. Pidana digunakan karena menyebabkan timbulnya keadaan yang lebih berbahaya atau merugikan daripada bila pidana tidak diterapkan. 


\begin{abstract}
Menurut G. Peter Hoefnagels sebagaimana pendapatnya dikutip oleh Harda Nawawi Arief dalam bukunya berjudul "Kebijakan Kriminal", upaya untuk menanggulangi kejahatan sesungguhnya dapat ditempuh melalui berbagai cara pendekatan, yaitu :
\end{abstract}
a. Dengan menerapkan hukum pidana (criminal law application)

b. Dengan pencegahan tanpa pidana (prevention without punishment)

$\begin{array}{lr}\text { c. } \begin{array}{l}\text { Dengan } \\ \text { pandangan }\end{array} & \text { masyarakat }\end{array}$ mengenai kejahatan pemidanaan lewat media massa (influecing views of society on crime and punishment/mass media). ${ }^{70}$

Pendapat yang diungkapkan di atas tersebut merupakan langkah atau strategi yang harus diperhatikan dalam upaya kebijakan perlindungan masyarakat, karena sesungguhnya penggunaan pidana dan hukum pidana dalam sebuah permasalahan bukan jalan keluar yang harus selalu dikedepankan. Kebijakan-kebjakan yang berbasis dengan tujuan memberikan kebijakan kesejahteraan sosial dapat dipergunakan untuk menjaga kontrol dalam masyarakat (social control) sehingga keseimbangan dalam masyarakat bisa terjaga satu sama lain.

\section{Metode Penelitian}

\section{Type Penelitian}

Tipe penelitian hukum $\begin{array}{lcr}\text { yang } & \text { dipergunakan } & \text { adalah } \\ \text { yuridis } & \text { normatif } & \text { (hukum }\end{array}$

${ }^{70}$ Dikutip oleh Abdul Kholiq AF, Op.Cit, hal. 264 normatif). Metode penelitian hukum normatif adalah suatu prosedur penelitian ilmiah untuk menemukan kebenaran berdasarkan logika keilmuan hukum dari sisi normatifnya ${ }^{71}$.

Oleh karena itu penelitian hukum ini difokuskan untuk mengkaji penelitian hukum tentang kaidah-kaidah atau norma-norma dalam hukum positif yang terkait dengan pokok permaslahan.

\section{Pendekatan Masalah}

Oleh karena type penelitian yang digunakan adalah type penelitian yuridis normatif, maka pendekatan masalah yang digunakan adalah pendekatan perundangundangan (Statute Approach). Pendekatan tersebut melakukan pengkajian pengaturan perundang-undangan yang berhubungan dengan pokok permasalahan. Selain itu juga digunakan pendekatan konsep (Conseptual Approach).

\section{Bahan Hukum}

a. Bahan Hukum Primer

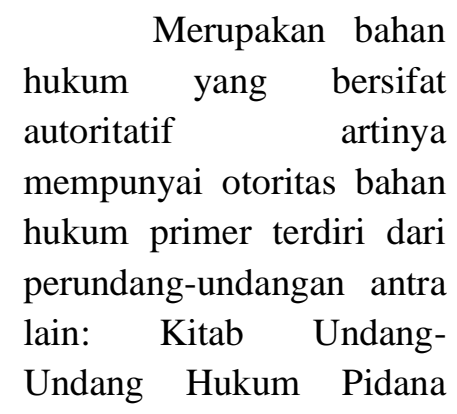

\footnotetext{
${ }^{71}$ Johnny Ibrahim, Teori Metode

Penelitian Normatif, Banyu Media

Publishing, Malang 2005. Hal 47
} 
(KUHP), Kitab Undang-

Undang Hukum Acara

Pidana (KUHAP).

b. Bahan sekunder

Berupa semua
publikasi tentang hukum
yang bukan merupakan
dokumen-dokumen resmi,
yaitu berupa buku teks,
kamus-kamus hukum,
jurnal-jurnal hukum dasar,
komentar-komentar atas
putusan pengadilan.

4. Prosedur Pengumpulan Bahan-bahan

Baik bahan primer maupun bahan sekunder dikumpulkan berdasar-kan topik permasalahan yang telah dirumuskan dan diklasifikasi menurut sumber dan hirarkinya untuk dikaji secara komprehensif.

\section{Pengolahan dan Analisis Bahan Hukum \\ Adapun bahan yang} diperoleh dalam penelitian studi kepustakaan, aturan perundangundangan, yang penulis uraikan dan dihubungkan sedemikian rupa, sehingga disajikan dalam penulisan yang lebih sistematis guna menjawab perumusan masalah yang dirumuskan. Cara pengolahan data dilakukan secara deduktif yakni menarik kesimpulan dari suatu permasalahan yang bersifat

\footnotetext{
${ }^{72}$ Peter Mahmud Marzuki. Penelitian Hukum. Universitas Air Langga. Surabaya. 2005. h
}

umum terhadap permasalahan kongkrit yang dihadapi.

E. Hasil Penelitian dan Pembahasan 1. Pengaturan Masalah Pelacuran Dalam Hukum Pidana Dan Peraturan Daerah Pengaturan masalah pelacuran dalam hukum pidana yang tertuang di dalam KUHP dalam tulisan ini adalah subyek-subyek yang memiliki peranan langsung dalam dunia pelacuran. Subyek tersebut adalah wanita pelacur, germo, dan tamu.

Bila memperhatikan pasal demi pasal yang ada di KUHP tidak ada satu pasal pun yang mengatur secara khusus mengenai wanita pelacur. Dengan tidak adanya pasal yang mengatur dalam KUHP, perbuatan melacur yang dilakukan WTS bukan dianggap kejahatan menurut hukum (legal definition of crime).$^{73}$ Walau bagaimana pun jahatnya suatu perbuatan bila hal tersebut tidak dilarang secara tugas dalam peraturan undang-undang pidana maka tidak dianggap sebagai sebuah kejahatan. Hal ini sesuai dengan apa yang tertuang dalam pasal 1 ayat 1 KUHP yang berbunyi

"Tiada satu perbuatan boleh dihukum, melainkan atas perbuatan ketentuan pidana dalam undang undang yang ada terdahulu daripada perbuatan itu".

Jika dilihat secara nyata bahwa perbuatan melacurkan diri seorang wanita bukan merupakan

${ }^{73}$ A.S Alam, Op. Cit, hal 66 
schuah kejahatan bila dilihat dari segi definisi kejahatan menurut atauran hukum, maka hal tersebut sangat bertentangan dengan definisi sosiologi dari kejahatan (sosiological definition of crime), yaitu apa yang disebut sebagai perbuatan jahat menurut normanorma sosial yang masih hidup di dalam masyarakat. ${ }^{74}$

$$
\text { Tetapi apa yang }
$$

diungkapkan kejahatan dari sudut sosiologi, masalah pelacuran dari sudut pandang agama, budaya, kesusilaan menurut berbagai lapisan masyarakat merupakan kejahatan yang dianggap berat karena perbuatan melacurkan diri dapat menurunkan moral dan meresahkan masyarakat. Sudut pandang itu sangat beralasan bila dilihat pada pola pikir masyarakat yang masih memegang tatanan moral dan kaedah agama yang demikian kuat.

Dengan tidak jelasnya
pengaturan perbuatan melacur
dalam KUHP, aparat kepolisian di Resort Lamongan sering menemui kesulitan dalam memproses perkara WTS. Hal ini terungkap dalam wawancara penulis dengan Kanit Samapta Adi Sasono yang menyatakan bahwa untuk mengadakan razia-razia terhadap pelacur kami selalu berusaha mencari dasar hukum yang tertuang di dalam buku ke-III KUHP, bab II mengenai pelanggaran terhadap kepentingan umum. Pasal-pasal terhadap pelanggaran ketertiban umum antara lain terdapat dalam pasal 505 dengan memuat ancaman

${ }^{74}$ Brown dan Brown dikutip dari A.S Alam, Ibid, hal. 67 hukuman terhadap orang-orang yang bergelandangan di jalan-jalan dan atau yang mengembara dengan tidak memiliki mata pencaharian.

Melihat bunyi pasal-pasal yang dituangkan dalam buKu ke III KUHP, Bab 11 yang biasa diterapkan oleh aparat kepolisian di Resort Lamongan maka tidaklah tepat bila pasal 505 dikenakan pada mereka. Pasal-pasal tersebut harusnya dikenakan terhadap orangorang yang bergelandangan dengan maksud mengemis atau memintaminta. Seorang pelacur yang berdiri di pinggir jalan atau berdiam di warung rernang-rernang yang tersebar di beberapa wilayah Kabupaten Lamongan tidak tepat bila dikenakan pasal-pasal tersebut, meskipun esensinva sama yaitu mengganggu ketertiban umum.

Mengenai penerapan pasal terhadap perbuatan pelacuran ini, menurut penulis dapat saja dimungkinkan kepada para pelacur dan tamu dengan pengenaan pasal tentang perzinahan, yaitu pasal 284 KUHP. Adapun definisi perzinahan menurut KUHP kita adalah :

"Seorang pria atau wanita yang telah terikat dalam sebuah pernikahan yang sah, melakukan zina dan salah satu dari mereka baik pihak pria atau wanita yang merasa dirugikan mengadukan hal delik yang ada dalam pasal perzinahan ini merupakan delik aduan, yang maksudnya adalah mereka yang melakukan perbuatan tersebut dapat dikenai pidana berdasar pasal 284 KUHP bila salah satu pihak dari mereka mengadukan hal tersebut." 
Selama ini dalam masalah pelacuran dua pihak yang terkait, baik itu pelacur ataupun tamunya banyak yang telah terikat dalam sebuah perkawinan. Ketika seorang wanita yang berprofesi sebagai pelacur dan melayani tamu atau pelanggannya, baik yang terikat dalam perkawinan yang sah ataupun tidak dan pihak suami dari pelacur itu merasa keberatan dengan apa yang dilakukan oleh istri, lalu akhirnya mengadukan masalah ini terhadap pihak berwajib maka penggunaan pasal 284 KUHP ini bisa saja dimungkinkan untuk diterapkan kepada mereka sebagai alternatif pengenaan pidana terhadap masalah ini. Begitu pula dengan para tamu yang melakukan hubungan badan dengan seorang pelacur. Bila tamu tersehut masih terikat dalam sebuah perkawinan dan pihak istri mengetahui perbuatan yang dilakukan oleh suami dan mengadukan hal ini, maka dapat pula tamu dijerat dengan pasal 284 tentang masalah perzinahan.

Tetapi pengenaan pasal 284 ini sebagai alternatif ancaman pidana terhadap masalah yang menyangkut pelacuran bukan berarti tanpa hambatan. Karena ditinjau dari unsur-unsur perbuatan pidana tentang masalah prostitusi jelas tidak dapat dipenuhi. Bagi pelacur yang unsur perbuatannya dapat diartikan menjual diri untuk melakukan hubungan badan dengan menerima jumlah tertentu sesuai dengan kesepakatan bersama, secara jelas terlihat sulit diterapkan dengan pasal perzinahan yang ada diatas karena pelacur itu melakukan perbuatan yang mereka jadikan sebagai mata pencaharian. Menurut penulis pasal ini memang dimungkinkan untuk diterapkan sebagai alternatif penanggulangan pelacuran selama rumusan pasal yang ada dalam pasal 284 itu dapat terpenuhi, karena tanpa adanya aduan-aduan dari para pihak yang merasa dirugikan maka mustahil aparat penegak hukum dapat menerapkan pasal ini.

Melihat penerapan pasal dalam KUHP untuk menanggulangi masalah pelacuran, dari wawancara yang penulis lakukan sebenarnya masih bisa pula dimungkinkan penerapan pasal 296 KUHP sebagai sebuah perbuatan yang sengaja mengadakan atau memudahkan perbuatan cabul dengan orang lain. Tetapi kendala yang ada dalam pasal 296 ini seharusnya ditujukan pada germo saja sebagai orang yang mengadakan bordil atau tempat pelacuran. ${ }^{75}$

Dalam kenyataannya wanita pelacur bukan pemilik dan pengusaha warung remang-remang tersebut, dan mereka juga sama sekali tidak menyuruh orang lain, tidak memiliki andil ataupun membujuk seseorang untuk mendirikan dan mengusahakan rumah bordil agar bisa memudahkan pelacuran. Hal inilah yang menimbulkan masalah aplikasi hukum agar masalah ini dapat ditanggulangi.

Seperti halnya dengan wanita pelacur, tamu dalam masalah

${ }^{75}$ Wawancara Lanjutan dengan Kasat Samapta AKP. Adi Sasono, pada Tanggal 20 April 2004 
pelacuran pun belum juga diatur secara tugas dalam KUHP. Melihat delik-delik kesusilaan yang diatur dalam KUHP yaitu berdasar pasal 281-303 para tamu yang menggunakan WTS sangat sulit nntuk dikenakan pidana. Sehingga selama ini dalam berbagai razia yang dilakukan penerapan hukum pidana sesuai dengan KUHP sangat tidak mungkinkan menjeratnya.

Berdasar pasal-pasal yang ada dalam KUHP kita sekarang ini, para tamu yang menggunakan wanita pelacur sangat sulit untuk dikenakan sanksi pidana. Hal ini bisa dibuktikan bila melihat rumusan pasal yang ada dalam KUHP kita. Dalam rumusanrumusan pasal tersebut unsur perbuatan pidana yang dilakukan tamu tidak dapat terpenuhi, sehingga apa yang dilakukan tamu seperti menggunakan jasa wanita pelacur untuk berhubungan badan dengan kesepakatan pembayaran jurnlah tertentu hampir dianggap bukan sebuah perbuatan pidana. Artinya di sini sandaran yuridis untuk mengenakan pidana terhadap para tamu sesuai unsurnya tidak dapat dipenuhi, kecuali seperti apa yang telah penulis singgung di atas tentang penerapan pasal perzinahan dalam pasal 284 KURP. Pasal ini merupakan delik aduan (Klacht Delict) yang memberikan kesempatan pula untuk menarik kembali aduan tersebut, selama pemeriksaan dalam sidang belum dimulai. Bila rumusan pasal 284 ini tidak dapat diterapkan maka secara otomatis pasal-pasal yang lain tidak dapat diterapkan kepada tamu yang menggunakan jasa wanita pelacur.
Terhadap para gemo sendiri, pasal yang diterapkan berkisar pada pengenaan pasal 296 dan pasal 506 KUHP. Pasal 296 sendiri adalah pasal yang berhubungan dengan orang yang menyediakan tempat untuk berbuat cabul dan pasal 506 mengatur makelar cabulnya. Seorang germo pada kenyataanya memang dapat diancam dengan pasal 296 maupun pasal 506 KUHP karena di samping ia menyediakan tempat untuk berbuat cabul juga sering menjadi perantara dari para pelacur.

Germo berdasar unsur-unsur pasal 296 memang memenuhi apa yang ada dalam pasal tersebut. Bunyi pasal 296 itu adalah sebagai berikut :

"Barang siapa dengan sengaja menghubungkan atau memudahkan perbuatan cabul oleh orang lain dengan orang lain, dan menjadikannya sebagai pencaharian atau kebiasaan diancam dengan pidana penjara paling lama satu tahun empat bulan atau denda paling banyak seribu rupiah". ${ }^{76}$

Mengenai pasal $296 \mathrm{R}$. Soesilo ini memberi komentar bahwa $^{77}$ :

a. Pasal ini gunanya untuk memberantas orang-orang yang mengadakan bordil atau tempat pelacuran yang banyak terdapat di kota-kota besar.

b. Supaya dapat dihukum harus dapat dibuktikan bahwa

\footnotetext{
${ }^{76}$ Moeljatno, KUHP, Bumi Aksara, Jakarta, 1996, hai. 108-109

${ }^{77}$ R. Soesilo, KUHP serta komentarkomentarnya lengkap pasal demi pasal, Politeia, Bandung, 1904, hal 169
} 
perbuatan itu menjadi mata pencahariannya atau kebiasaannya.

c. Tentang perbuatan cabul lihat pasal 289 yang termasuk ke dalam persetubuhan.

d. Yang dikenakan pasal ini misalnya orang menyediakan rumah atau kamarnya kepada perempuan atau laki-laki untuk melacur (bersetubuh atau melepaskan nafsu kelaminnya dengan jalan lain) di situ.

Begitu juga dengan apa

yang terdapat dalam pasal 297

KUHP, yang berbunyi :

"Perdagangan wanita dan laki-laki yang belum cukup umur diancam dengan pidana penjara paling lama enam tahun". ${ }^{78}$

Terhadap rumusan pasal di atas seharusnya para germo dapat pula dijerat dengan pasal ini, karena tidak sedikit pula dalam banyak kasus yang terjadi di lapangan seorang germo mendatangi gadisgadis yang tinggal di daerah pedesaan di mana dijanjikan pekerjaan tertentu di kota-kota besar dengan gaji yang cukup besar tetapi pada kenyataannnva setelah gadisgadis tersebut sarnpai di kota yang dimaksud, mereka dijual kepada germo-germo kelas kakap dan lalu dipekerjakan sebagai seorang wanita penghibur untuk melayani pelanggan yang ada. Modus operandi seperti ini biasanya dilakukan dalam tipe pelacuran kelas tinggi, sehingga dari hasil penjualan gadis-gadis yang berasal dari daerah-daerah yang dilakukan germo-germo tersebut maka pasal perdagangan wanita dalam pasa1297
KUHP ini dapat diterapkan kepada mereka.

Selain kenyataan di atas, banyak pula kasus terjadi di mana para wanita yang berasai dari desa dijanjikan pekerjaan dengan gaji yang cukup besar tetapi sesampainya di kota yang dijanjikan mereka dipekerjakan sebagai wanita pelacur. Berkaitan dengan kenyataan ini, seorang germo bisa saja dikenakan pasal 378 KUHP tentang penipuan, karena pada kenyataannya mereka tidak memenuhi janji yang diberikan kepada para gadis-gadis tersebut.

Mengenal pasal ini $\mathrm{R}$. Soesilo juga berkomentar ${ }^{79}$ :

a. Yang dimaksud dengan "perniagaan atau perdagangan wanita" ialah melakukan perbuatan-perbuatan dengan maksud untuk menyerahkan perempuan guna pelacuran. Masuk pula mereka di sini yang biasanya mencari pertempuanperempuan muda untuk dikirimkan ke luar negeri yang maksudnya tidak lain akan digunakan untuk pelacuran

b. Yang diancam hukuman bukan hanya perdagangan perempuan, melainkan juga perdagangan orang laki-laki yang belum dewasa.

c. Perdagangan budak belian dikenakan pasal 324 dan berikutnya.

Terhadap rumusan pasal di atas seharusnya para germo dijerat oleh pasal ini. Tetapi pada kenyataannya mereka tidak pernah ditangkap dan diadili sesuai pasal yang tertuang dalam KUHP ini. 
Begitu pula dengan mucikari yang dikenal sebagai calo atau perantara para WTS. Mereka hampir tidak pernah dijerat oleh aturan hukum yang ada dalam KUHP, padahal mereka juga sebagai subyek dalam pelacuran.

Pasal yang mengatur para mucikari ini dapat terlihat pada pasal 506 KUHP, yang berbunyi :

"Barangsiapa menarik keuntungan dari perbuatan cabul seorang wanita dan menjadikannya sebagai mata pencaharian diancam dengan kurungan paling lama satu tahun', ${ }^{80}$

\section{Politik Hukum Pidana dan Politik Kriminal Sebagai Bagian Dari Politik Sosial}

Politik kriminal (criminal policy) sebagai usaha yang rasional untuk menanggulangi kejahatan merupakan bagian dari politik penegakan hukum dalam arti luas (law enforcment policy). Semuanya merupakan bagian dari politik sosial (social policy), yakni usaha dari masyarakat atau negara untuk meningkatkan kesejahteraan warganya. ${ }^{81}$

Proses penentuan kebijakan hukum pidana adalah sebuah usaha yang rasional untuk meningkatkan kehidupan yang lebih baik pada masyarakat secara menyeluruh. Sebagai bagian dari politik sosial, politik hukum pidana dan politik kriminal merupakan satu bagian

${ }^{80}$ Moeljatno, Op. Cit, hal. 184

81 Ibid. hal. 3, dikutip dari Barda Nawawi Arief, Bunga Rampai Hukum Pidana. yang tak dapat dipisahkan dalam upaya memberikan perlindungan terhadap masyarakat.

Usaha yang dilakukan tersebut berawal dari sebuah tindak kriminal atau kejahatan yang dapat meresahkan masyarakat yang merupakan salah satu bentuk perilaku menyimpang. ${ }^{82}$

Menurut Saparinah Sadli perilaku menyimpang tersebut menciptakan ancaman terhadap norma sosial yang mendasari kehidupan atau keteraturan sosial dan memberikan ancaman nyata bagi berlangsungnya ketertiban sosial. ${ }^{83}$ Dan penanggulangan untuk menyelesaiakan masalah sosial tersebut dalam masyarakat telah banyak dilakukan, salah satunya adalah dengan menggunakan hukum pidana dan penerapan sanksi di luar pidana.

Penggunaan upaya hukum berupa hukum pidana sebagai salah satu upaya mengatasi masalah sosial termasuk dalam bidang penegakan hukum karena tujuannya berorientasi pada mencapai kesejahteraan masyarakat pada umumnya, maka kebijakan penegakan hukum itu termasuk dalam bidang kebijakan sosial, sehingga penggunaan hukum pidana bukan merupakan keharusan untuk dilakukan. ${ }^{84}$ Hal ini tidak lepas dari politik kriminal yang di dalamnya

${ }^{82}$ Saparinah Sadli, Persepsi Sosial Tentang Prilaku Menyimpang, Bulan Bintang, Jakarta, 1976, hal. 56.

${ }^{83}$ Ibid, hal. 25-26

${ }^{84}$ Muladi dan barda Nawawi Arief, Op.Cit, hal. 149 
menyatakan bahwa upaya penanggulangan kejahatan sebagai bagaian dari kebijakan sosial juga perlu memperhatikan aspek non penal (di luar hukum pidana), selama penggunaan sarana non penal itu bisa berhasil maka penggunaan sarana penal dapat diminimalisir perannya.

dalam $\begin{gathered}\text { Menurut } \\ \text { upaya }\end{gathered}$ kejahatan masih memerlukan pidana dan hukum pidana. Hal itu antara lain bisa berupa : ${ }^{85}$

1) Perlu tidaknya hukum pidana tidak terletak persoalan tujuantujuan yang hendak dicapai, tapi terletak pada persoalan seberapa jauh untuk mencapai tujuan itu boleh menggunakan paksaan. Persoalannya bukan terletak pada hal yang akan dicapai, tapi dalam pertimbangan antara nilai dan hasil itu dan nilai dari batasbatas kebebasan pribadi masingmasing.

2) Ada usaha-usaha perbaikan yang tidak memiliki arti sama sekali bagi si terhukum dan di samping itu harus tetap ada suatu reaksi atas pelanggaranpelanggaran norma yang telah dilakukannya itu dan tidaklah dibiarkan begitu saja.

3) Pengaruh pidana atau hukum pidana bukan sesuatu yang ditujukan kepada penjahat, tetapi juga untuk mempengaruhi orang yang tidak jahat yaitu warga masyarakat yang menaati norma-norma masyarakat.

Roeslan Saleh nampaknya tetap mempertahankan perlunya pidana dan pidana sebagai politik kriminal dan dari sudut tujuan, fungsi dan pengaruh dari hukum

${ }^{85}$ Roeslan Saleh, Ibid, hal. 153 pidana itu sendiri. Istilah yang digunakan olehnya ialah masih adanya dasar susila dari hukum pidana.

Sejalan dengan pertimbangan mengenai kemungkinan suatu politik kriminal yang cukup rasioanal Karl O. Christiansen yang pendapatnya dikutip oleh Barda Nawawi Arief, menyatakan :

"Pengaruh hukum pidana terhadap masyarakat luas sangat sulit diukur. Pengaruh itu (maksudnya pengaruh dalam arti general prevention) terdiri dari sejumlah bentuk aksi dan reaksi yang berbeda dan saling berkaitan erat, yang disebut dengan berbagai macam nama, misalnya pencegahan umum (General prevention) memperkuat kembali nilai-nilai moral (re inforcement of moral public), memperkuat kesadaran kolektif (strengthening the collective solidarity), menegaskan kembali rasa aman dari masyarakat (re affirmation of the public feeling of security), mengurangi atau meredakan ketakutan (alleviation of fears), melepaskan keteganganketegangan agresif (release of aggresivetensions) dan sebagainya" ${ }^{86}$

\section{E. Penutup}

\section{Kesimpulan}

86 Karl. O. Christiansen, Some Considerantion on The Possibility of Rational Policy, dikutip dari Barda Nawawi Arief, Beberapa Aspek dan Penegakan Hukum, Citra Aditya Bakti, hal. 43. 
Berdasarkan uraian yang telah penulis sampaikan di dalam masalah pelacuran dan cara penanggulangnnva dalam perspektif politik hukum pidana, maka dapat disimpulkan :

a. Aturan-aturan hukum yang tertuang dalam KUHP selama ini belum mampu menindak mereka karena beberapa pasal yang menyangkut dalam hal ini masih dianggap kurang efektif. Hal ini bisa dibuktikan dengan pasal-pasal yang antara lain pada pasal 296, 297, dan 506. Berkaitan dengan hal ini seharusnya aturan-aturan di dalam pasal-pasal KUHP harus dilakukan perubahan karena penindakan yang dilakukan oleh aparat penegak hukum selama ini hanya menitikberatkan pada upaya penanggulangan para wanita pelacur, sedangkan genno, mucikari maupun tamu tidak pernah ditindak, padahal mereka juga menjadi mata rantai dalam masalah pelacuran ini.

b. Kebijakan penal dan non penal yang selama ini dilakukan dalam penanggulangan pelacuran terutama oleh Pemerintah Daerah Kabupaten Lamongan merupakan usaha dalam bidang politik kriminal yang di dalamnya berisi usahausaha penanggulangan kejahatan termasuk masalah pelacuran ini, sehingga upayaupaya yang dilakukan dari berbagai macam sudut kebijakan dapat meminimalisirnya. Namun usaha yang berbasis pada penanggulangan secara penal maupun non penal kurang menunjukan hasil yang menggembirakan. Hal ini bisa dilihat dengan belum adanya Peraturan daerah yang mengatur masalah pelacuran ini padahal perangkat hukum untuk memback up aturan hukum pidana yang sudah ada sangat diperlukan sebagai sebuah garis kebijakan daerah bersangkutan untuk menanggulangi pelacuran. Begitu pula dengan kebijakan dalam bidang non penal dalam penanggulangn hal ini. Pemda Lamongan hanya menitikberatkan pada pola penanganan yang terhadap wanita pelacur saja. Pihak-pihak lain seperti germo dan tamu tidak pernah diusahakan pola penanganannya padahal justru dalam mengatasi masalah ini mereka yang menjadi subyek itu merupakan mata rantai yang secara terpadu harus diberikan pola penanganan yang seimbang.

\section{Saran}

a. Pasal-pasal di dalam KUHP harus segera diperbaiki kembali, karena KUHP sekarang di dalam mengatur masalah pelacuran pasalpasal yang berkenaan dengan hal itu tidak mampu digunakan secara efektif agar masalah ini dapat diupayakan usaha meminimalisirnya. Setidak-tidaknya dalam KUHP yng baru nanti rumusan perbuatan pidana terhadap para pihak dalam masalah pelacuran harus lebih jelas lagi sehingga aparat penegak hukum tidak mengalami kesulitan dalam mengenakan pasal-pasal yang ada dalam KUHP.

b. Kebijakan-kebijakan dalam hukum pidana juga harus mampu melahirkan kebijakan yang rasional dalam menanggulangi masalah ini, karena bila kebijakan hanya ditekankan pada aspek pemidanaannya 
saja maka hal itu tidak akan berjalan dengan baik. Oleh karena itu kebijakan yang berorientasi pada nilai-nilai filosotis. yuridis, dan sosiologis diharapkan mampu membuat sebuah kebijakan yang cukup baik dalam usaha mengatasi masalah ini. Kebijakan yuridis ini dimaksudkan, bahwa dalam membuat sebuah kebijakan hukum, aspek hukum dari sebuah perbuatan harus dilihat apakah merupakan perbuatan yang melanggar hukum atau tidak, sedang aspek filosofis menyangkut dengan nilai-nilai dari perbuatan yang akan diusahakan untuk diherikan kebijakan. Dan mengenai aspek sosiologis seharusnya perlu memperhatikan pada apa yang berkembang dalam masyarakat. Artinya pandanan-pandang masyarakat tentang perbuatan pelacuran ini menurut pola pikir masyarakat itu seperti apa sehingga upaya yang mengadopsi pola pikir masyarakat dapt memberlkan konstribusi yang berarti.

\section{DAFTAR PUSTAKA}

\section{LITERATUR:}

Ali Akbar, Pelacuran dan Penyakit Kelamin, Dian Kemaka, Departemen Sosial RI, Jakarta

Johnny Ibrahim, Teori Metode

Penelitian Normatif, Banyu Media Publishing, Malang 2005

Karl. O. Christiansen, Some Considerantion on The Possibility of Rational Policy, dikutip dari Barda Nawawi Arief, Beberapa
Aspek dan Penegakan Hukum, Citra Aditya Bakti

Peter Mahmud Marzuki. Penelitian Hukum. Universitas Air Langga. Surabaya. 2005

R. Soesilo, KUHP serta komentarkomentarnya lengkap pasal demi pasal, Politeia, Bandung, 1994

Saparinah Sadli, Persepsi Sosial Tentang Prilaku Menyimpang, Bulan Bintang, Jakarta

Soedjono.D, Pelacuran Ditinjau Dari Segi Hukum Dan Kenyataan Dalam Masyarakal, Karya Nusantara, Bandung, 1977

Soedikno Mertokusumo, Mengenal Hukum Suatu Pengantar, Liberty, Yogyakarta, 1998

Soedjono D. Dikutip oleh Mudzakkir dalam Peranan Psikologi dalam Penerapan Hukum Pidana, FHUII, Yogyakarta, 1985

Van Apeldoorn, Pengantar Ilmu Hukum, Cetakan ke lima, Liberty, Yogyakarta, 2000

Zaini Dahlan dan Sahil Azharudin, $A l$ Qur'an Karim dan Terjemahan Artinya, UII Press, Yogyakarta.

\section{Peraturan Perundang-Undangan}

Kitab Undang-Undang Hukum Pidana (KUHP)

\section{KUHAP}

